\title{
Mass-production of human dendritic cells in accordance with gmp for clinical studies
}

\author{
Yui Harada ${ }^{1 *}$, Noriko Yasuda', Yoshikazu Yonemitsu ${ }^{2}$ \\ From 30th Annual Meeting and Associated Programs of the Society for Immunotherapy of Cancer (SITC 2015) \\ National Harbor, MD, USA. 4-8 November 2015
}

\section{Background}

Although clinical studies have established that antigenloaded dendritic cells (DCs) vaccines are safe and promising therapy for various kinds of malignancies, their clinical efficacy remains to be established. Issues that limit the clinical efficacy of DC-based immunotherapy, as well as the difficulty of the industrial production of DCs, are largely due to the limited number of autologous DCs available from each patient (Kato T., et al. Neoplasia 2010), and it is necessary to prepare an enough number of DCs for effective treatments of tumors. In this study, therefore, we attempted to expand functional human DCs of cancer patients ex vivo.

\section{Methods}

The method to produce DCs, prepared in accordance with Good Manufacturing Practice (GMP) guidelines, is an optimization of ex vivo preparation method for generating large numbers of DCs from peripheral blood mononuclear cells (PBMCs) obtained by leukapheresis for clinical studies. Several fraction-depleted PBMCs were expanded and differentiated into DCs in the presence of optimal cytokine cocktails for 3-4 weeks by floating cultivation.

\section{Results}

By this method, about $1 \times 10^{9} \mathrm{CD}_{11 \mathrm{c}^{+}}$cells could be obtained. These cells had typical features (endocytotic activity, expression of HLA-DR, adhesion molecules, chemokine receptor and co-stimulatory molecules, production of inflammatory cytokines, allo-MLR activity and positive for tetramer assay) of conventional myeloid DCs in vitro. Therefore, the concept of DC expansion

${ }^{1}$ R\&D Laboratory for innovative Biotherapeutics, Graduate School of Pharmaceutical Sciences, Fukuoka, Japan

Full list of author information is available at the end of the article should contribute significantly to the progress of DC immunotherapy.

\section{Conclusions}

We established a new culture method to expand human DCs. Expanded DCs had properties that were required to obtain therapeutic gain. Thus, we expect that this technology will improve therapeutic gain of cancer and alleviate patients' burden of apheresis, and be able to contribute largely to both basic and clinical research of human cancer immunotherapy.

\section{Authors' details}

${ }^{1}$ R\&D Laboratory for innovative Biotherapeutics, Graduate School of Pharmaceutical Sciences, Fukuoka, Japan. ${ }^{2}$ R\&D Laboratory for Innovative Biotherapeutics, Graduate School of Pharmaceutical Sciences, Kyushu University, Fukuoka, Japan.

Published: 4 November 2015

doi:10.1186/2051-1426-3-S2-P207

Cite this article as: Harada et al: Mass-production of human dendritic cells in accordance with gmp for clinical studies. Journal for

ImmunoTherapy of Cancer 2015 3(Suppl 2):P207.

Submit your next manuscript to BioMed Central and take full advantage of:

- Convenient online submission

- Thorough peer review

- No space constraints or color figure charges

- Immediate publication on acceptance

- Inclusion in PubMed, CAS, Scopus and Google Scholar

- Research which is freely available for redistribution 